\title{
Organic Water Additive on Growth Performances, Hematological Parameters and Cost Effectiveness in Broiler Production
}

\author{
Munmun Saha ${ }^{1}$, Sachidananda Das Chowdhury ${ }^{1}$, Md. Elias Hossain ${ }^{1,2}$, Md. Kamrul Islam ${ }^{3}$ and Bishwajit Roy ${ }^{4}$ \\ ${ }^{1}$ Department of Poultry Science, Bangladesh Agricultural University, Mymensingh-2202, Bangladesh, ${ }^{2}$ Department of Animal \\ Science and Technology, Sunchon National University, Suncheon 540-742, South Korea, ${ }^{3}$ Department of Physiology, \\ Bangladesh Agricultural University, Mymensingh-2202, Bangladesh, ${ }^{4}$ Renata Animal Health, Dhaka, Bangladesh
}

\begin{abstract}
The experiment was conducted with 144 broiler chicks from day-old to 5 weeks of age to investigate the efficacy of a water additive in broiler production. The chicks were randomly distributed into four different treatments namely $\mathrm{T} 1$ (control), T2 (water additive as per recommendation level), T3 (25\% less than recommendation) and T4 (25\% more than recommendation). Body weight of control group was higher in 2nd week of age, but at the end of the experiment additive groups showed higher values compare to control $(\mathrm{p}<0.05)$. Body weight gain was increased and feed conversion ratio was improved in the additives groups during the finishing and total period, although feed intake was different among the additive groups ( $<<0.05$ ). When the hematological parameters were evaluated, packed cell volume and total erythrocytes counts were increased in the additive group that received $25 \%$ more than recommendation, and hemoglobin in $25 \%$ less than recommendation group. Mean cell volume and mean cell hemoglobin of the additive groups showed lower $(\mathrm{p}<0.05)$ values compare to the control, but other parameters were not affected. Sales price and profit were significantly higher in the additive groups compare to the control, although total production cost was increased in the additive groups $(\mathrm{p}<0.05)$. All levels of water additive increased profit in comparison with the control but $25 \%$ less than recommendation level appeared to be most profitable and cost effective. It also suggests that any additive considered for poultry, must undergo trial for determining efficacy as well as its cost effectiveness for application.
\end{abstract}

(Key words : Water additive, Growth performances, Hematological parameters, Cost effectiveness, Broiler)

\section{INTRODUCTION}

The routine use of in-feed antibiotics in animal feeding has created growing public concern regarding bacterial resistance and residues in animal products such as meat, egg and milk (Domig, 2005). It is a growing challenge for feed manufacturers to design and manufacture products that are safe and efficacious as well as acceptable to increasingly attentive consumers. The use of natural growth promoters (NGP) such as acidifier, probiotics, prebiotics, phytogenic etc. are regarded as key strategy to support gut health, to counteract pathogenic germs and to optimize digestive functions (Steiner, 2006).

Plant extracts contain a vast source of different molecules which have intrinsic bio-activities on animal physiology and metabolism. Such extracts are the ingredients of many commercial preparations currently used in animal production that have antimicrobial (Jamroz et al., 2003, Manzanilla et al., 2004), antioxidant (Ertas et al., 2005; Cross et al., 2007), and are able to improve digestibility (Rao et al., 2003), stimulate enzyme activity (Platel et al., 2002) and immune functions (Watzl et al., 2005, Ko and Yang, 2008). The results of previous studies indicated that the addition of plant product as feed additive might be considered as a potential NGP in broiler production (Alcicek et al., 2003; Cabuket al., 2006; Ertas et al., 2005). Lysozyme, also known as muramidase is a non-antibody protective enzymes that can reduce or replace antibiotics used for growth promotion in broiler chicks by its antibacterial properties and improve feed efficiency (Sotirov et al., 2000). On the other hand, both muramidase and peroxidase decrease intestinal harmful bacteria, and animals therefore could have a better feed conversion. Fructooligosaccharide (FOS) increases the number and activity of beneficial bacteria in the colon of animals and poultry. It can be substituted for antibiotics to enhance the growth performance (Wu et al., 1999) and to significantly

* Corresponding author:Md. Elias Hossain, Department of Animal Science and Technology Sunchon National University, Suncheon 540-742, South Korea. Tel: 010-3705-3276, Fax: 061-750-3239, E-mail: mehossain_bau@yahoo.com 
increase average daily gain of broilers (Xu et al., 2003). Vitamin $\mathrm{E}$ and Vitamin $\mathrm{C}$ promote improved resistance of body against infection and stress that improved feed utilization and feed conversion ratio as well as decrease broiler mortality (Villar-Patino et al., 2002; Sosnowka- Czajka et al., 2005).

Most of the studies on feed or water additive have dealt with either single or a combination of two or three active principles. Therefore, information regarding the efficacy of a blend of a number of active principles is scanty in the literature. The current study was an attempt to investigate the effect of an organic water additive lisovit, which containing muramidase, peroxidase, oligosaccharide, vitamin $\mathrm{E}$, vitamin $\mathrm{C}$ and plant extract on the productive performances, hematological parameters and cost effectiveness of floor reared commercial broilers.

\section{MATERIALS AND METHODS}

\section{Broilers and experimental design}

The study was conducted with 144 day-old commercial broiler chicks (Cobb 500) for a period of 5 weeks. The chicks were randomly distributed into four different treatment groups namely, T1 (control), T2 (water additive as per recommendation level), T3 (25\% less than recommendation), T4 (25\% more than recommendation) with three replications in each treatment. The number of birds in each replication was 12. All birds received a starter diet from $0 \sim 3$ weeks and a finisher diet from $4 \sim 5$ weeks. The water additive lisovit consist (per $\mathrm{kg}$ ) of muramidase (lysozyme, 5X108 SU), peroxidase $(120 \mathrm{~g})$, fructooligosaccharide $(30 \mathrm{~g})$, herbal extract (390 g), vitamin E (2.5 g) and vitamin C (150 g) (Biomin, Austria). All diets were formulated to meet or exceed the nutrient requirements of broiler chickens (NRC, 1994). The ingredients composition and estimated nutrients content of the diets are shown in Table 1.

\section{Broilers management}

The house and necessary equipments were properly cleaned, washed and disinfected, subsequently dried and left them empty for a week before the arrival of chicks. Water additive was properly mixed with fresh, cool and clean drinking water and supplied to the experimental birds once in the morning and again in the afternoon. It was added to
Table 1. Ingredients and chemical composition of the diet

\begin{tabular}{lcc}
\hline Items & $\begin{array}{c}\text { Starter } \\
(0 \sim 3 \text { week })\end{array}$ & $\begin{array}{c}\text { Finisher } \\
(4 \sim 5 \text { week })\end{array}$ \\
\hline \hline Ingredients (\%, as feed basis) & & \\
Yellow corn & 57.37 & 59.44 \\
Soybean meal & 26.50 & 25.40 \\
Rice polish & 5.00 & 4.70 \\
Soybean oil & 2.00 & 2.20 \\
Protein concentrate & 5.50 & 5.00 \\
Salt & 0.25 & 0.25 \\
Dicalcium phosphate & 1.64 & 1.50 \\
Limestone & 0.92 & 0.88 \\
Vitamin-Mineral premix ${ }^{1)}$ & 0.30 & 0.30 \\
Choline & 0.08 & 0.07 \\
L-lysine & 0.24 & 0.16 \\
Methionine & 0.20 & 0.10 \\
Total & 100 & 100 \\
\hline Chemical composition $(\%$, dry matter basis $)$ & \\
Crude protein & 22.50 & 21.00 \\
Crude fat & 4.00 & 4.50 \\
Crude fiber & 6.00 & 6.00 \\
Methionine & 0.79 & 0.70 \\
Calcium & 0.90 & 0.85 \\
Available phosphorus & 0.54 & 0.52 \\
ME (kcal/kg) & 3100 & 3150 \\
\hline Provided & & \\
\hline & &
\end{tabular}

${ }^{1)}$ Provided the following nutrients per $\mathrm{kg}$ of diet: Vitamin A, 6,000 IU; vitamin D3, $800 \mathrm{IU}$; vitamin E, $20 \mathrm{IU}$; vitamin K3, 2 $\mathrm{mg}$; thiamin, $2 \mathrm{mg}$; riboflavin, $4 \mathrm{mg}$; vitamin $\mathrm{B} 6,2 \mathrm{mg}$; vitamin B12, $1 \mathrm{mg}$; pantothenic acid, $11 \mathrm{mg}$; niacin, $10 \mathrm{mg}$; biotin, 0.02 $\mathrm{mg}$; $\mathrm{Cu}, 21 \mathrm{mg}$; Fe, 100mg; Zn, $60 \mathrm{mg}$; Mn, 90mg; I, $1.0 \mathrm{mg}$; Co, $0.3 \mathrm{mg}$; Se, $0.3 \mathrm{mg}$.

drinking water twice in a week at 1st, 3rd and 5th week of age according to manufacturer instruction. Fresh, clean and dried rice husk was used as litter materials at a depth of about $3 \mathrm{~cm}$. The litter and housing area were disinfected with a safe and suitable disinfectant in every alternate day. Care was taken to ensure proper ventilation with the advancement of age of birds. The birds were exposed to a continuous lighting of 23 hours and a dark period of 1 hour in 24 hours. They were vaccinated against Gumboro and Newcastle Diseases.

\section{Growth performance measurement}

The body weight of broilers was measured every week 
from the initial day to the final day of the experiment to calculate the body weight gain. The feed intake of broilers was recorded by offering a weighed quantity of feed and weighing their residues on a weekly basis. The feed conversion ratio (FCR) was calculated based on amount of feed consumed to the body weight gain of the broilers.

\section{Hematological analysis}

Five $\mathrm{ml}$ of blood was collected from jugular vein from three birds considering randomly from each group and stored in a sterilized test tube containing $0.5 \mathrm{ml}$ anticoagulant sodium citrate $(4 \%)$ at a ratio of $1: 10$. The hematological studies were performed within two hours of blood collection. The hematological parameters such as total erythrocyte count (TEC), hemoglobin $(\mathrm{Hb})$, packed cell volume (PCV), erythrocyte sedimentation rate (ESR), mean cell volume (MCV), mean cell hemoglobin concentration (MCHC) and mean cell hemoglobin $(\mathrm{MCH})$ were determined by routine methods as previously described (Jain, 1986).

\section{Cost analysis and statistical analysis}

Cost analysis was performed considering market price of inputs and outputs. Profitability was determined considering the cost incurred for water additive. Data were analyzed using the general linear models of SAS (2003) to estimate variance components with a completely randomized design. Duncan's multiple comparison tests were used to examine significant differences among the treatment means. The level of significance was set at $\mathrm{p}<0.05$. Data are presented as mean values \pm standard error.

\section{RESULTS AND DISCUSSION}

\section{Growth performance}

Body weight was affected when the additive was added with the water of broilers (Fig. 1). Body weight of the control group was increased in 2nd week of age, but at the end of the experiment, $25 \%$ less and $25 \%$ more than recommendation group exhibited a higher body weight compare to the control group $(\mathrm{p}<0.05)$. Body weight gain in the total period was same as body weight, but the additive groups had higher value than the control in finishing period $(\mathrm{p}<0.05)$ (Table 2). The water additive tested in this study improved weight gain over control by $6.8,7.7$ and $7.5 \%$ due to its addition at recommended level, a level of $25 \%$ less and $25 \%$ more respectively. Table 2 shows that feed intake was significantly reduced $(\mathrm{p}<0.05)$ in the finishing period when the water additive was applied $25 \%$ more than recommended, but when considered the whole period, birds

Table 2. Growth Performance of broilers treated with different levels of water additive

\begin{tabular}{|c|c|c|c|c|}
\hline \multirow{2}{*}{ Parameters } & \multicolumn{4}{|c|}{ (reatment ${ }^{1)}$} \\
\hline & $\mathrm{T} 1$ & $\mathrm{~T} 2$ & $\mathrm{~T} 3$ & $\mathrm{~T} 4$ \\
\hline \multicolumn{5}{|l|}{ Body weight gain (g/bird) } \\
\hline Starter $(0 \sim 3$ weeks $)$ & $641.11 \pm 4.44$ & $613.95 \pm 19.20$ & $619.39 \pm 14.91$ & $628.34 \pm 1.39$ \\
\hline Finisher (4 5 weeks) & $795.56^{\mathrm{b}} \pm 11.79$ & $920.61^{\mathrm{a}} \pm 31.18$ & $927.83^{\mathrm{a}} \pm 28.66$ & $916.67^{\mathrm{a}} \pm 22.05$ \\
\hline Total (0 5 weeks) & $1436.67^{\mathrm{b}} \pm 15.78$ & $1534.56^{\mathrm{ab}} \pm 47.12$ & $1547.22^{\mathrm{a}} \pm 29.29$ & $1545.00^{\mathrm{a}} \pm 22.05$ \\
\hline \multicolumn{5}{|l|}{ Feed intake ( $\mathrm{g} / \mathrm{bird})$} \\
\hline Starter (0 3 weeks) & $922.78 \pm 5.05$ & $922.64 \pm 1.18$ & $930.83 \pm 6.14$ & $937.78 \pm 6.74$ \\
\hline Finisher (4 5 weeks) & $1886.11^{\mathrm{a}} \pm 6.81$ & $1880.70^{\mathrm{a}} \pm 1.41$ & $1886.53^{\mathrm{a}} \pm 7.82$ & $1857.36^{\mathrm{b}} \pm 6.12$ \\
\hline Total (0 5 weeks) & $2808.89^{\mathrm{b}} \pm 2.02$ & $2803.34^{\mathrm{c}} \pm 0.42$ & $2817.36^{\mathrm{a}} \pm 2.24$ & $2795.14^{d} \pm 0.85$ \\
\hline \multicolumn{5}{|c|}{ Feed conversion ratio (feed/gain) } \\
\hline Starter $(0 \sim 3$ weeks $)$ & $1.44 \pm 0.01$ & $1.51 \pm 0.05$ & $1.50 \pm 0.03$ & $1.49 \pm 0.01$ \\
\hline Finisher (4 5 weeks) & $2.37^{\mathrm{a}} \pm 0.04$ & $2.05^{\mathrm{b}} \pm 0.07$ & $2.04^{\mathrm{b}} \pm 0.07$ & $2.03^{\mathrm{b}} \pm 0.05$ \\
\hline Total (0 5 weeks) & $1.95^{\mathrm{a}} \pm 0.02$ & $1.83^{\mathrm{b}} \pm 0.06$ & $1.82^{\mathrm{b}} \pm 0.04$ & $1.81^{\mathrm{b}} \pm 0.03$ \\
\hline
\end{tabular}

\footnotetext{
${ }_{a, b, c, d}$ Means with uncommon superscripts in a same row are significantly different $(\mathrm{p}<0.05)$.
}

${ }^{1)} \mathrm{T} 1$ : control; $\mathrm{T} 2$ : water additive as per recommendation; $\mathrm{T} 3$ : water additive $25 \%$ less than recommendation; T4: water additive $25 \%$ more than recommendation. 


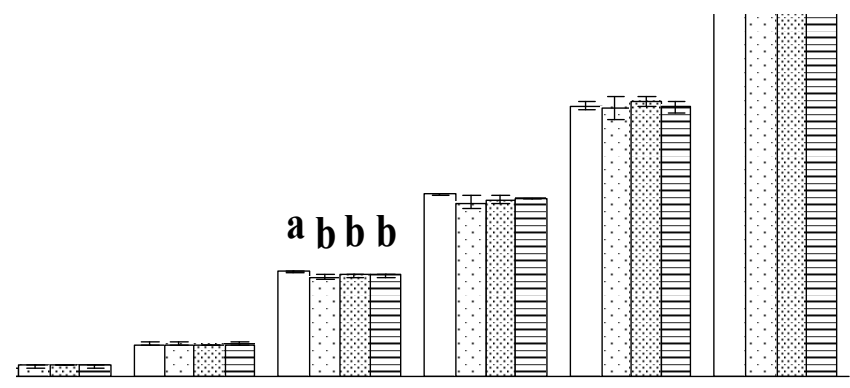

nitial 1st wk 2nd wk 3rdwk 4th wk 5thwk

Fig. 1. Body weight of broilers treated with different levels of water additive. Data are presented as mean \pm standard error. Means within a time class not sharing a common superscript are significantly different $(P<0.05)$. T1: control; T2: water additive as per recommendation; T3: water additive $25 \%$ less than recommendation; T4: water additive $25 \%$ more than recommendation.

receiving $25 \%$ less than recommended showed higher value compare to other treatments. A decreasing $(\mathrm{p}<0.05)$ trend in values of FCR was observed in all water additive treated groups from the control in finishing and total periods, indicating that the additive improves the feed efficiency.

It appears from such a result that increasing or decreasing the level of the water additive by $25 \%$ from recommended level may be equally effective for growth promotion of broilers. Results of the application of phytobiotics in the nutrition of broiler chickens are not completely consistent. Some authors state significant positive effects on broiler performance (Ertas et al., 2005) whereas others found no differences (Cross et al., 2007). In addition, Alcicek et al. (2003) evaluated an herbal extract and stated that it may be considered as a potential growth promoter in broiler production. Fukata (1999) and $\mathrm{Wu}$ et al. (1999) reported increased growth rate as a consequence of FOS inclusion in broiler diets, whereas Williams et al. (2008) reported that FOS reduced daily live weight gain. However, SosnowkaCzajka et al. (2005) and Bhat et al. (1999) found no significant difference on growth rate between treatment group and control due to addition of vitamin $\mathrm{E}$ and $\mathrm{C}$ in the diet. Although feed intake was higher in birds, receiving 25\% less than recommended, but it was not affected FCR of this group. The improvement of FCR by the additive component lysozyme was previously reported by Humphrey et al. (2002), who stated that lysozyme significantly reduced feed intake and improved feed efficiency than those fed the control diet and was effective in improving feed efficiency as antibiotics. In contrast, Sosnowka-Czajka et al. (2005) and Sirbue et al. (1986) found no significant difference in feed conversion in birds fed vitamin E, while Villar-Patino et al. (2002) stated that diets containing vitamin $\mathrm{C}$ decreased feed consumption and FCR. In addition, Lower feed intake was also reported by Williams et al. (2008) and Cabuk et al. (2006), who observed that the birds given FOS and essential oil mixtures (herbal extract) had a lower feed intake as compared to control. It is assumed that the cumulative affect of the additive components increase the weight gain and improve the feed efficiency.

\section{Hematological parameters}

The results of hematological parameters are displayed in Table 3. The values of TEC in all treated birds were significantly $(\mathrm{p}<0.05)$ higher than the values of control group. The highest value of TEC was in $25 \%$ more than recommendation group and lowest in the control group. The difference in $\mathrm{Hb}$ content between recommended and $25 \%$ less than recommendation groups was statistically significant $(\mathrm{p}<0.05)$ and $25 \%$ less than recommendation group showed the highest value. The highest PCV value was found in $25 \%$ more than recommendation group which differed from that of the control $(\mathrm{p}<0.05)$ group. $\mathrm{MCV}$ and $\mathrm{MCH}$ in birds receiving additive at different doses differed significantly $(p<0.05)$ from the control, but MCHC was not affected. Lysozyme plays an important role in the non-specific immunity. Extracts from medicinal plants had a stimulatory effect on the levels of lysozyme and properdine in the blood serum (Lavinia et al., 2009). WBC, RBC, PCV and $\mathrm{Hb}$ content were improved when broiler fed diets contain plant extracts derived from thyme and cinnamon(Al-Kassie, 2009). However, Basavaraj et al. (2011) reported no significant effect of turmeric rhizome powder on PCV, $\mathrm{Hb}$. TEC, TLC in broilers. Vitamin $\mathrm{C}$ increase $\mathrm{WBC}$ and may improve immunity, facilitate the adaptation response to against stress and decrease negative effects on production in chickens (Cinar et al., 2006). In addition, Shlig (2009) found an improvement of hematological parameter by the supplementation of vit $\mathrm{E}$ to aflatoxin challenged broilers. Although MCV and MCH decreased in additive groups, but the values of these parameters are in line with the report by Talebi et al. (2005). The hematological parameters of present findings are not in agreement with the findings of Tras et al. (2000) 
Table 3. Hematological parameters of broilers treated with different levels of water additive

\begin{tabular}{|c|c|c|c|c|}
\hline \multirow{2}{*}{ Parameters $^{2)}$} & \multicolumn{4}{|c|}{ Treatment $^{1)}$} \\
\hline & $\mathrm{T} 1$ & $\mathrm{~T} 2$ & $\mathrm{~T} 3$ & $\mathrm{~T} 4$ \\
\hline PCV (\%) & $23.99^{\mathrm{b}} \pm 0.66$ & $24.87^{\mathrm{ab}} \pm 1.28$ & $26.87^{\mathrm{ab}} \pm 1.07$ & $27.78^{\mathrm{a}} \pm 0.49$ \\
\hline $\operatorname{TEC}\left(10^{3} / \mathrm{mm}^{3}\right)$ & $1.64^{\mathrm{c}} \pm 0.09$ & $2.18^{\mathrm{b}} \pm 0.05$ & $2.14^{\mathrm{b}} \pm 0.05$ & $2.47^{\mathrm{a}} \pm 0.03$ \\
\hline $\mathrm{Hb}(\mathrm{g} / \mathrm{dL})$ & $8.07^{\mathrm{ab}} \pm 0.09$ & $7.33^{b} \pm 0.03$ & $8.75^{\mathrm{a}} \pm 0.37$ & $8.21^{\mathrm{ab}} \pm 0.48$ \\
\hline $\operatorname{ESR}(\mathrm{mm}$ in $1 \mathrm{st} \mathrm{h})$ & $1.80 \pm 0.06$ & $2.00 \pm 0.01$ & $1.78 \pm 0.40$ & $1.89 \pm 0.11$ \\
\hline MCV (fL) & $147.07^{\mathrm{a}} \pm 7.75$ & $113.88^{\mathrm{b}} \pm 4.60$ & $125.63^{b} \pm 7.14$ & $112.69^{b} \pm 3.20$ \\
\hline $\mathrm{MCH}(\mathrm{pg})$ & $49.48^{\mathrm{a}} \pm 2.50$ & $33.62^{\mathrm{c}} \pm 0.62$ & $40.88^{b} \pm 1.94$ & $33.33^{\mathrm{c}} \pm 2.28$ \\
\hline $\mathrm{MCHC}(\mathrm{g} / \mathrm{dL})$ & $33.68 \pm 0.91$ & $29.64 \pm 1.53$ & $32.59 \pm 0.84$ & $29.55 \pm 1.55$ \\
\hline
\end{tabular}

${ }^{a, b, c}$ Means with uncommon superscripts in a same row are significantly different $(\mathrm{p}<0.05)$.

${ }^{1)} \mathrm{T} 1$ : control; $\mathrm{T} 2$ : water additive as per recommendation; $\mathrm{T} 3$ : water additive $25 \%$ less than recommendation; $\mathrm{T} 4$ : water additive $25 \%$ more than recommendation.

${ }^{2)} \mathrm{PCV}$ : packed cell volume; TEC: total erythrocyte count; Hb: hemoglobin; ESR: erythrocyte sedimentation rate; MCV: mean cell volume; $\mathrm{MCH}$ : Mean cell hemoglobin; MCHC: mean cell hemoglobin Concentration.

and Al-Rawashdeh et al. (2000), who found no significant effect of vitamin E, ascorbic acid and oligosaccharide supplementation of any of hematological parameters in broiler. The changes as observed in this study might be due to the initiative effects on hemopoitic organ that were more active and developed in additive groups than that of control and the digestive system became well balanced to absorb proper level of essential nutrients which are needed for erythropoiesis. The increase in TEC, PCV and $\mathrm{Hb}$ concentration of blood also indicate the good condition of broiler health (Elangovane et al., 2001).

\section{Cost analysis}

The results of cost analysis are presented in Table 4. Production cost involved cost of bird, feed, water additive and maintenance (disinfectant, vaccine, transport, labor, water and electricity). The additive cost varied significantly $(p<0.05)$ among the additive groups. Total production cost, sales price and profit of broilers receiving additive significantly varied from the control $(\mathrm{p}<0.05)$ group, but not different among the additive groups. Lowest cost (\$1.882) was found in the control group while additive groups showed the higher cost (\$1.913-1.921) as would be expected. When sales price/bird was considered, it was found that the additive groups had higher values than the control as because birds of these groups had better body weight. In case of profit/broiler and profit/kg broiler, higher profit was

Table 4. Cost analysis of broilers treated with different levels of water additive

\begin{tabular}{lcccc}
\hline Parameters & \multicolumn{4}{c}{ Treatment $^{\mathrm{l})}$} \\
\cline { 2 - 5 } & $\mathrm{T} 1$ & $\mathrm{~T} 2$ & $\mathrm{~T} 3$ & $\mathrm{~T} 4$ \\
\hline \hline Feed cost (\$/broiler) & $1.073 \pm 0.005$ & $1.073 \pm 0.006$ & $1.079 \pm 0.005$ & $1.069 \pm 0.005$ \\
Additive cost (\$/broiler) & - & $0.032^{\mathrm{b}} \pm 0.001$ & $0.024^{\mathrm{c}} \pm 0.001$ & $0.040^{\mathrm{a}} \pm 0.001$ \\
Total production cost (\$/broiler) & $1.882^{\mathrm{b}} \pm 0.006$ & $1.913^{\mathrm{a}} \pm 0.007$ & $1.913^{\mathrm{a}} \pm 0.006$ & $1.921^{\mathrm{a}} \pm 0.005$ \\
Sales price $(\$ /$ broiler) & $2.164^{\mathrm{b}} \pm 0.011$ & $2.313^{\mathrm{a}} \pm 0.011$ & $2.333^{\mathrm{a}} \pm 0.011$ & $2.327^{\mathrm{a}} \pm 0.012$ \\
Profit $(\$ /$ broiler) & $0.283^{\mathrm{b}} \pm 0.017$ & $0.400^{\mathrm{a}} \pm 0.005$ & $0.420^{\mathrm{a}} \pm 0.017$ & $0.406^{\mathrm{a}} \pm 0.017$ \\
Profit $(\$ / \mathrm{kg}$ broiler) & $0.192^{\mathrm{b}} \pm 0.012$ & $0.254^{\mathrm{a}} \pm 0.0034$ & $0.265^{\mathrm{a}} \pm 0.011$ & $0.256^{\mathrm{a}} \pm 0.011$ \\
Profit over control $(\$ / \mathrm{kg}$ broiler) & - & $0.063 \pm 0.015$ & $0.073 \pm 0.022$ & $0.065 \pm 0.022$ \\
\hline
\end{tabular}

${ }^{a, b, c}$ Means with uncommon superscripts in a same row are significantly different $(\mathrm{p}<0.05)$.

${ }^{1)} \mathrm{T} 1$ : control; T2: water additive as per recommendation; T3: water additive $25 \%$ less than recommendation; T4: water additive $25 \%$ more than recommendation. 
found in additive groups, and 25\% less than recommended group exhibited highest values $(\$ 0.420$ and $\$ 0.265)$. Profit over control among the additive groups was not statistically different, but $25 \%$ less than recommended group earned higher profit (\$0.073) compare to others. The result is an agreement with the previous study by Oh and Max (1980), who found a higher income over feed cost per bird (\$0.13) in additive group. In addition, Rahman et al. (2005) and Hosamani et al. (2001) also reported an increased profit by addition of enzyme mixture to broilers diet.

It may be concluded that the productive performances of broilers treated with water additive $25 \%$ less or more than recommended levels were higher than control. There was no adverse effect of the test material on hematological parameters of broiler that could affect productivity and profitability. Though addition of additive in water increased the production cost of broiler, return in terms of profitability supports its inclusion, but a level less than $25 \%$ of recommended level provides highest profit and therefore most cost effective. The study also suggests that feed or water additive considered for poultry, must undergo trials to determine efficacy, correct dose as well as its cost effectiveness.

\section{REFERENCES}

Al-Kassie, G. A. M. 2009. Influence of two plant extracts derived from thyme and cinnamon on broiler performance. Pak. Vet. J. 29:169-173.

Al-Rawashdeh, O. F., Gumaa, A. V., Saeed, M., Orban, J. I., Patierson, J. A. and Nour, A. V. M. 2000. Effects of sucrose thermal oligosaccharide caramel and feed restriction on the performance, hematological values and cecal bacteriological counts of broiler chickens. Acta Vet. 50:225-240.

Alcicek, A., Bozkurt, M. and Cabuk, M. 2003. The effect of an essential oil combination derived from selected herbs growing wild in turkey on broiler performance. S. Afr. J. Anim. Sci. 33:89-94.

Basavaraj, M., Nagabhushana, V., Prakash, N., Appannavar, M. M., Wagmare, P. and Mallikarjunappa, S. 2011. Effect of dietary supplementation of Curcuma longa onthe biochemical profile and meat characteristics of broiler rabbits under summer stress. Vet. World. 4:15-18.

Bhat, G. A., Wani, S. A. and Ganai, T. A. S. 1999. Effect of feeding vit $\mathrm{E}$ on the performance of broilers under temperate agro-climate condition. Indian J. Poult. Sci. 34:83-85.
Cabuk, M., Bozkurt, M. and Alcicek, A. 2006. The effect of a mixture of herbal essential oils on the performance of broiler chicks originated from young and old broiler breeder flocks. S. Afr. J. Anim. Sci. 36:135-141.

Cinar, A., Belge, F., Donmez, N., Tas, A., Selcuk, M. and Tatar, M. 2006. Effects of stress produced by adrenocorticotropin (ACTH) on ECG and some blood parameters in vitamin C treated and non-treated chickens. Vet. Arhiv. 76:227-235.

Cross, D. E., Mcdevitt, R. M., Hillman, K. and Acamovic, T. 2007. The effect of herbs and their associated essential oils on performance, dietary digestibility and gut microflora in chickens from 7 to 28 days of age. Br. Poult. Sci. 48: 496-506.

Domig, K. J. 2005. Antibiotikaresistenz und der Einsatz von Antibiotika in der Tierernahrung. 4. BOKU-Symposium Tierernahrung: Tierernahrung ohne Antibiotische Leistungsforderer. Vienna, Austria. pp.1-8.

Elangovan, A. V., Verma, S. V. S., Sastry, V. R. B. and Singh, S. D. 2001. Rapeseed meal as a protein supplement in diets for growing Japanese quail. Arch. Geflugelk. 65:114-117.

Ertas, O. N., Guler, T., Ciftci, M., Dalkilic, B. and Simsek, U. G. 2005. The effect of an essential oil mix derived from oregano, clove and anise on broiler performance. Int. J. Poult. Sci. 4:879-884.

Fukata, T., Sasai, K., Miyamoto, T. and Baba, E. 1999. Inhibitory effects of competitive exclusion and fructooligosaccharide, singly and in combination, on Salmonella colonization of chicks. J. Food Prot. 62:229-233.

Hosamani, S. V., Shivakumar, M. C., Kulkarni, V. S. and Harapanahailli, M. D. 2001. Effect of supplementing dietary enzymes on the performance of broilers; Karnataka J. Agric. Sci. 14:1046-1048.

Humphrey, B. D., Huang, N. and Klasing, K. C. 2002. Rice expressing lactoferrin and lysozyme has antibiotic like properties when fed to chicks. J. Nutr., 132:1214-1218.

Jain, N. C. 1986. Schalm's Veterinary Hematology. 4th ed. Lea and Febrigen, Philadelphia, USA. pp: 34-50.

Jamroz, D., Orda, J., Kamel, C., Wiliczkiewicz, A., Wertelecki, T. and Skorupinska, J. 2003. The influence of phytogenic extracts on performance, nutrient digestibility, carcass characteristics, and gut microbial status in broiler chickens. J. Anim. Feed Sci. 12:583-596.

Ko, S. Y. and Yang, C. J. 2008. Effect of green tea probiotics on the growth performance, meat quality and immune response in finishing pigs. Asian-Aust. J. Anim. Sci. 21:1339-1347.

Lavinia, S., Gabi, D., Drinceanu D., Stef D., Daniela, M., Julean, 
C., Ramona, T. and Corcionivoschi, N. 2009. The effect of medicinal plants and plant extracted oils on broiler duodenum morphology and immunological profile. Rom. Biotechnol. Lett. 14:4606-4614.

Manzanilla, E. G., Perez, J. F., Martin, M., Kamel, C., Baucellss, F. and Gasa, J. 2004. Effect of plant extracts and formic acid on the intestinal equilibrium of early-weaned pigs. J. Anim. Sci. 82:3210-3218.

NRC. 1994. Nutrient requirements of poultry. 9th rev. ed. National Research Council, National Academy Press. Washington, DC.

Oh, B. T. and Mak, T. K. 1980. Production performance of broilers fed different feed additives. Pertanika 3:53-55.

Platel, K., Rao, A., Saraswathi, G. and Srinivasan, K. 2002. Digestive stimulant action of three Indian spices mixes in experimental rats. Nahr. 46:394-398.

Rahman, M. M., Mollah, M. B. R., Islam, F. B. and Howlider, M. A. R. 2005. Effect of enzyme supplementation to parboiled rice polish based diet on broiler performance. Livest. Res. Rural Develop. 17. Available at: http://www.lrrd.org/lrrd17/4/ rahm17038.htm.

Rao, R. R., Platel, K. and Srinivasan, K. 2003. In vitro influence of spices and spice-active principles on digestive enzymes of rat pancreas and small intestine. Nahr. 47:408412.

SAS. 2003. SAS User's Guide, Version 9.1 ed. SAS Institute, Cary, NC.

Shlig, A. A. 2009. Effect of vitamin E and selenium supplement in reducing aflatoxicosis on performance and blood parameters in broiler chicks. Iraqi J. Vet. Sci. 23:97-103.

Sirbue, M., Tureu, D. and Rotunheanu, E. 1986. Effect of dietary vitamin $\mathrm{E}$ of feed intake and growth of meat and egg strain chicks, Nutr. Abst. Rev. Ser. B. 53:4370.

Sosnowka-Czajka, E., Skomorucha, I. and Herbut, E. 2005. Effect of dietary vitamin supplements on productivity and physiological parameters of broiler chickens exposed to elevated ambient temperature, ISAH-Warsaw, Poland. Available at: http://www.isah-oc.org/documents/2005/sections/24_vol_2.pdf. Sotirov, L. K, Deney, S. A. and Georgieva, V. K. 2000. Effect of different growth promoters on lysozyme and complement activity of broiler chicks. Bulg. J. Agric. Sci. 6:75-82.

Steiner, T. 2006. Managing gut health-natural growth promoters as a key to animal performance. Nottingham University press, Nottingham, UK.

Talebi, A., Asri-Rezaei, S., Rozeh-Chai, R. and Sahraei, R. 2005. Comparative studies on haematological values of broiler strains (Ross, Cobb, Arbor-acres and Arian). Int. J. Poult. Sci. 4:573-579.

Tras, B., Inal, F., Bas, A. L., Altunok, V. M. and Yazar, E. 2001. Effects of continuous supplementation of ascorbic acid, aspirin, vit $\mathrm{E}$ and selenium on some hematological parameters and serum superoxide dismutase level in broiler chicks. Br. Poult. Sci. 41:664-666.

Villar-Patino, G., Diaz-Cruz, A., Avila-Gonzalez, E., Guinzberg, R., Pablos, J. L. and Pina, E. 2002. Effects of dietary supplementation with vitamin $\mathrm{C}$ or vitamin $\mathrm{E}$ on cardiac lipid peroxidation and growth performance in broilers at risk of developing ascites syndrome. Am. J. Vet. Res. 63:673-676.

Watzl, B., Girraback, S. and Roller, M. 2005. Inulin, oligofructose and immunomodulation. Br. J. Nutr. 93 (Suppl.1):S49-S55.

Williams, J., Mallet, S., Leconte, M. and Gabriel, I. 2008. The effect of fructo-oligosaccarides or whole wheat on the performance and digestive tract of broiler chickens. Br. Poult. Sci. 49:329-339.

Wu, T. X., Dai, X. J. and Wu, L. Y. 1999. Effects of fructooligosaccharide on the broiler production. Acta Agric. Zhejiangensis. 11:85-88.

Xu, Z. R., Hu, C. H., Xia, L. M. S., Zhan, X. A. and Wang, M. Q. 2003. Effects of dietary fructooligosaccharide on digestive enzyme activities, intestinal microflora and morphology of male broilers. Poult. Sci. 82:1030-1036.

(Received Nov. 7, 2011; Revised Dec. 7, 2011; Accepted Dec. 8, 2011) 